\title{
PHYLOGENETIC RELATIONSHIPS OF INSECT-ASSOCIATED FREE-LIVING RHABDITID NEMATODES FROM EASTERN MEDITERRANEAN REGION OF TURKEY
}

\author{
AZIZOGLU, U. $.^{*}-$ KARABÖRKLÜ, S. ${ }^{2}-$ AYVAZ, A. ${ }^{3}-$ YILMAZ, S. ${ }^{4}$ \\ ${ }^{I}$ Department of Crop and Animal Production, Erciyes University, P.O. Box 38900 Kayseri, \\ Turkey. \\ ${ }^{2}$ Department of Field Crops, Düzce University, P.O. Box 81620 Düzce, Turkey. \\ ${ }^{3}$ Department of Biology, Erciyes University, P.O. Box 38039 Kayseri, Turkey. \\ ${ }^{4}$ Department of Agricultural Biotechnology, Erciyes University, P.O. Box 38400 Kayseri, \\ Turkey. \\ *Corresponding author \\ e-mail: azizoglu@erciyes.edu.tr \\ (phone: +90-537-596-22-66; fax: +90-352-437-82-64) \\ (Received $15^{\text {th }}$ Feb 2016; accepted $12^{\text {th }}$ Apr 2016)
}

\begin{abstract}
Free-living nematodes play an important role in nutrient cycling. The study was designed to characterize insect-associated free-living soil nematodes in Rhabditida order from Eastern Mediterranean region of Turkey using their 28S rDNA sequences and phylogenetic analysis. A total of 105 soil samples were taken from different habitats. Galleria baiting technique was used to obtain free-living nematodes. The nematodes were harvested from cadavers of last instar Galleria mellonella larvaeafter trapping process. Free-living soil nematodes were detected in 14 soil samples (13.3\%). PCR products obtained from $28 \mathrm{~S}$ rDNA of isolates were sequenced and phylogenetic trees created. BLASTN homology searches and phylogenetic tree results constructed by Neighbour Joining and Bootstrap Tree methods. Results showed that these insect-associated isolates were determined as species belonging to Rhabditidae (Rhabditis terricola and Mesorhabditis sp.), Chambersiellidae (Macrolaimus sp.) and Cephalobidae (Cephalobus sp., Pseudacrobeles sp. and Acrobeloides sp.) families in Rhabditida. Free-living nematodes interact with many arthropods and other invertebrate species. These interactions are also important for their use in biological control program. In this study, these interactions between free-living nematodeinsect,-arthropod and-invertebrate are discussed.
\end{abstract}

Keywords: DNA sequence analysis, phylogeny, nematode-insect association, free-living soil nematode, Rhabditida

\section{Introduction}

Nematodes (roundworms) are the most common, abundant, and genetically diverse metazoan organisms found in many habitats particularly soils and sediments, even in the most extreme environments (Baldwin et al., 1999; Derycke et al., 2008). Rhabditida order (rhabditids) is an interesting nematode group found in abundance in all kinds of soil. The free-living forms of this organisms display different feeding habits such as saprophagous or bacteriophagous, and as animal parasites (enthomopathogenic forms) (Yeates et al., 1993; Abolafia and Pena-Santiago, 2007). Because of their abundance, rapid life cycle, and strong interactions with other soil microbes and predators, freeliving nematodes play an important role in nutrient cycling (Yeates and Wardle, 1996; Ferris et al., 1997; Carrascosa et al., 2014). Their functional guilds respond to food web enrichment, environmental perturbation, and recovery (Wang et al., 2004). They 
indirectly contribute to nitrogen mineralization by grazing on decomposer microbes, excreting ammonium, and immobilizing nitrogen in live biomass (Ferris et al., 1998; Neher, 2001). Due to their high occurrence, diversity, different tropic levels, and sensitivity to abiotic alterations free-living nematodes also contribute as bioindicators to environmental pollution and soil quality studies (Levi et al., 2012). Their high phenotypic plasticity among populations reduces the number of diagnostic characters in rhabditid nematode groups. Thus their classification has been a matter of long and strong discussions and diversity is far from being well known (Nadler, 2002; Abolafia and Pena-Santiago, 2007; Derycke et al., 2008). Molecular techniques and phylogenetic analyses can potentially overcome this problem and are promising tools to assess biodiversity (Derycke et al., 2008). In recent years, DNA sequence data have brought a revival in the field of systematic (Blaxter et al., 1998; De Ley and Blaxter, 2002; Subbotin et al., 2006). Rhabditids have been identified on the basis of large subunit (LSU or 28S) ribosomal DNA (rDNA) sequences. Trees inferred from LSU or $28 \mathrm{~S}$ rDNA sequences have been used in deducing relationships among certain closely related species, primarily congeners (De Ley et al., 1999; Stock et al., 2001; Nadler et al., 2003).

The study was planned to characterize insect-associated free-living soil nematodes in Rhanditida order from East-Mediterranean Turkey using their 28S rDNA sequences and phylogenetic analysis.

\section{Materials and methods}

\section{Nematode isolation}

A total of 105 soil samples were taken from different locations and habitats in Adana, Osmaniye and Kahramanmaraş provinces at October 2010 (Table 1) (Karabörklü, 2012). Soil samples were baited with last instar Galleria mellonella L. (Lep.: Pyralidae) larvae (Bedding and Akhurst, 1975) for screening entomopathogenic nematodes (EPN) in our previous study (Karabörklü, 2012; Karabörklü et al., 2015a). However, many rhabditid nematodes also detected during these procedures (Duncan et al., 2003, Campos-Herrera et al., 2012). These rhabditid nematodes harvested from dead G. mellonella larvae were placed individually into modified White traps (Kaya and Stock 1997) at room temperature $\left(\sim 25^{\circ} \mathrm{C}\right)$. Harvested nematodes were washed in $\mathrm{dH}_{2} \mathrm{O}$ and stored at $10^{\circ} \mathrm{C}, 60 \% \pm 5$ relative humidity and full darkness until DNA extraction (Karabörklü, 2012; Karabörklü et al., 2015a).

\section{DNA extraction and PCR amplification}

DNA extraction and PCR amplification were done as described in our previous study with some modifications in method suggested by Williams et al. 1994 (Karabörklü, 2012; Karabörklü et al., 2015a,b). DNA was extracted by using 10-20 nematodes. In 20 $\mu 1$ of worm lysis buffer $(50 \mathrm{mM} \mathrm{KCl}, 0.05 \%$ gelatin, $10 \mathrm{mM}$ Tris $\mathrm{pH} 8.2,10 \mathrm{mM}$ DTT, $0.45 \%$ Tween $20,2.5 \mathrm{mM} \mathrm{MgCl} 2$ and $60 \mu \mathrm{g} \mu \mathrm{l}^{-1}$ proteinase $\mathrm{K}$ ) nematodes were cut and transferred to sterile microfuge tubes $(0.5 \mathrm{ml})$ on ice. Lysate were frozen at $-80^{\circ} \mathrm{C}$ for 20 min and then incubated at $65^{\circ} \mathrm{C}$ for $1 \mathrm{~h}$, followed by inactivation of proteinase $\mathrm{K}$ for 15 min at $95^{\circ} \mathrm{C}$ (Zhang et al., 2008). The lysates were centrifuged at $6000 \mathrm{rpm}$ for $30 \mathrm{sec}$ after cooling. Then, $2.5 \mu \mathrm{l}$ DNA suspension were added to a PCR reaction mixture containing $2.5 \mu \mathrm{l}$ of $10 \mathrm{X}$ PCR buffer, $1.5 \mu 1$ of $25 \mathrm{mM} \mathrm{MgCl}_{2}, 1 \mu 1$ of $10 \mathrm{mM}$ dNTP 
mixture, $1 \mu \mathrm{l}$ of each primer pair $(100 \mu \mathrm{M}), 0.25 \mu \mathrm{Taq}$ polymerase $\left(5 \mathrm{U}^{-1} \mathrm{l}^{-1}\right)$ and completed to $25 \mu \mathrm{l}$ with distilled water. $28 \mathrm{~S}$ rDNA primer pairs 5'F'AGCGGAGGAAAAGAAACTAA-3' and 5'-R'ATCCGTGTTTCAAGACGGG-3' were used in amplification reaction (Nadler and Hudspeth, 1998). PCR was adjusted at $94{ }^{\circ} \mathrm{C}$ for $3 \mathrm{~min}$, followed by 33 cycles of $94{ }^{\circ} \mathrm{C}$ for $30 \mathrm{sec}, 52{ }^{\circ} \mathrm{C}$ for $30 \mathrm{sec}$, and $72{ }^{\circ} \mathrm{C}$ for $1 \mathrm{~min}$, followed by final extension at $72{ }^{\circ} \mathrm{C}$ for $7 \mathrm{~min}$ (Stock et al., 2001). Electrophoresis was performed on $1 \%$ agarose gel.

\section{Phylogenetic analysis}

PCR products were purified using of PCR purification kit (Fermentas) and sequenced by RefGen Biotechnology Laboratory (METU, Turkey). Alignments of sequences were performed using the National Centre for Biological Information's (NCBI) Basic Local Alignment Search Tool (BLAST) to compare the sequence data with known sequences submitted on the NCBI. Phylogenetic and molecular evolutionary analyses were conducted using MEGA version 5 (Tamura et al., 2011; Yilmaz et al., 2012). Phylogenetic trees were constructed using the Neighbor Joining (NJ) and Bootstrap Tree (BT) methods (based on 1000 bootstrap replications) of the MEGA version 5 program. Alignment gaps and missing data were eliminated in pairwise sequence comparisons (Karabörklü et al., 2015a).

\section{Results}

\section{Isolates}

Free-living soil nematodes were detected in 14 out of 105 soil samples (13.3\%) (Table 1). Nematodes were harvested from cadavers of last instar G. mellonella larvae after trapping process. Nematode densities on cadavers varied depending on isolates. SK-3, SK-16, SK-18 and SK-75 were the highest, SK-20 and SK-51 were medium, and SK-13, SK-29, SK-30, SK-32, SK-34, SK-76, SK-94 and SK-101 isolates were the lowest in density. Nematodes were isolated from forests, grasslands, and agricultural fields. Percentage of the nematodes isolated from forest, grassland, agronomical and horticultural areas were found to be 13.3, 13.3, 46.7 and 26.7\%, respectively (Table 1).

Table 1. Nematode isolation regions and their habitation properties

\begin{tabular}{lll}
\hline Isolate & Isolation region & Habitat \\
\hline SK-3 & Pozant1/Adana & Forest (Pinery) \\
SK-13 & Kozan/Adana & Horticultural area (Citrus orchard) \\
SK-16 & Sülemişli-Feke/Adana & Grassland \\
SK-18 & Saimbeyli/Adana & Grassland \\
SK-20 & Pınarlar-Tufanbeyli/Adana & Agronomical area (Wheat field) \\
SK-29 & Selimiye/Osmaniye & Agronomical area (Cornfield) \\
SK-30 & Akyar/Osmaniye & Agronomical area (Cornfield) \\
SK-32 & Toprakkale/Osmaniye & Agronomical area (Cornfield) \\
SK-34 & Ceyhan/Adana & Horticultural area (Olive orchard) \\
SK-51 & Çona/Osmaniye & Agronomical area (Peanut field) \\
SK-75 & Süleymanlı Yolu/Kahramanmaraş & Forest (Pinery) \\
SK-76 & Süleymanlı/Kahramanmaraş & Horticultural area (Grape orchard) \\
SK-94 & Yeniköy/Osmaniye & Agronomical area (Cornfield) \\
SK-101 & Buruk-Sarıçam/Adana & Horticultural area (Citrus orchard) \\
\hline
\end{tabular}




\section{Molecular identification}

$28 \mathrm{~S}$ rDNA PCR products of the isolates were individually purified and sequenced. Isolates were clustered on the basis of genus. Isolates compared with 20 nematode species showing highest similarity. Detailed phylogenetic analysis was given previously for each isolate. SK-3 and SK-75 isolates were indicated 99 and $98 \%$ identity with Rhabditis terricola (EF417152) after BLASTN homology search, respectively. Phylogenetic tree was constructed using the Neighbor Joining (NJ) and Bootstrap Tree (BT) methods for two nematode species were given in Figure 1. Similarly, SK-13 displayed 95\% identity with Pseudacrobeles variabilis (AF143368) (Fig. 2). Similarity rates and Bootstrap Trees (BT) of other isolates were given in Table 2 and Figures (3-6).

Table 2. Similarity rates of free-living nematode isolates with accession numbers

\begin{tabular}{llc}
\hline Isolates (AN) & Species (AN) & Similarity (\%) \\
\hline SK-3 (KP027186) & Rhabditis terricola (EF417152) & 99 \\
SK-13 (KP027183) & Pseudacrobeles variabilis (AF143368) & 95 \\
SK-16 (KP027182) & Acrobeloides maximus strain JB-89 (DQ903097) & 95 \\
SK-18 (KP027184) & Acrobeloides sp. JB-68 (DQ903091) & 99 \\
SK-20 (KP027191) & Cephalobus sp. PS-1143(DQ903100) & 99 \\
SK-29 (KP027193) & Macrolaimus sp. SAN-2005 (DQ145639) & 94 \\
SK-30 (KP027181) & Acrobeloides nanus (EF417139) & 88 \\
SK-32 (KP027189) & Acrobeloides sp. JB-68 (DQ903091) & 97 \\
SK-34 (KP027190) & Acrobeloides sp. JB-68 (DQ903091) & 99 \\
SK-51 (KP027192) & Cephalobus sp. PS-1143(DQ903100) & 99 \\
SK-75 (KP027185) & Rhabditis terricola (EF417152) & 98 \\
SK-76 (KP027194) & Mesorhabditis longespicula strain DF5017 (EU195980) & 92 \\
SK-94 (KP027187) & Acrobeloides sp. DWF-1106 (DQ903080) & 80 \\
SK-101 (KP027188) & Acrobeloides sp. DWF-1106 (DQ903080) & 89 \\
\hline
\end{tabular}

AN: Accession Number

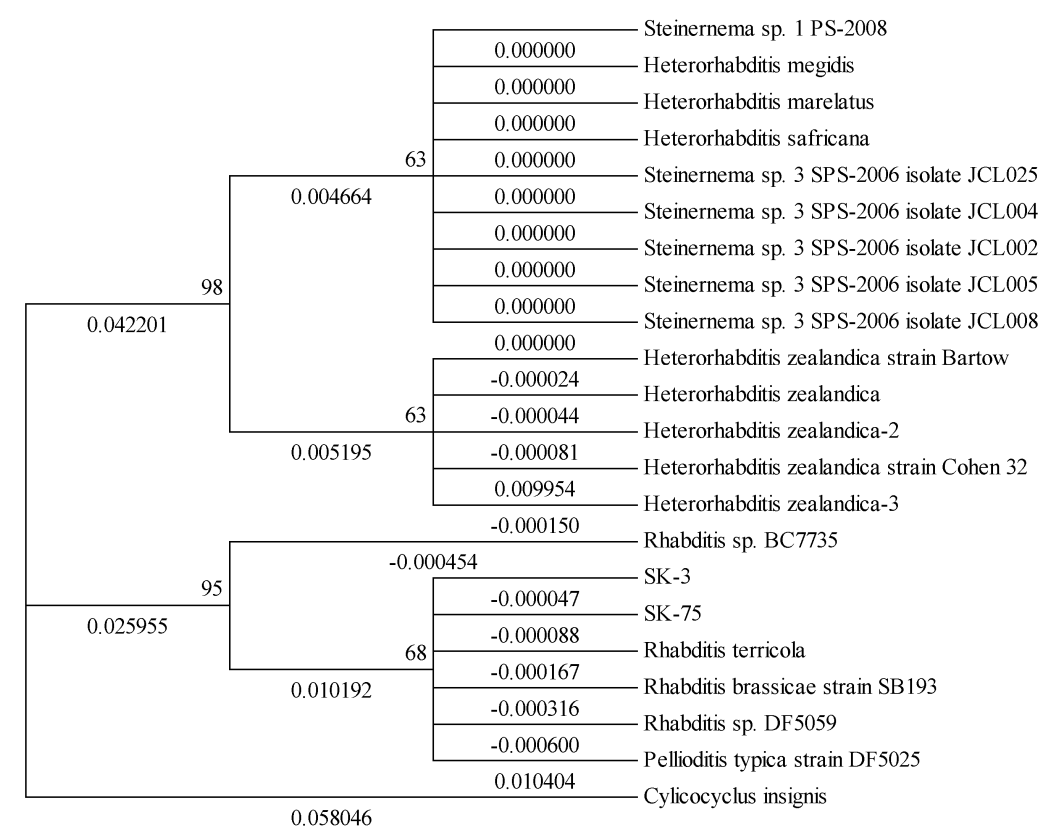

Figure 1. Phylogenetic relationships of different nematode species with $S K-3$ and SK-75 isolates. Phylogeny inferred from the alignment of the 719 and 583bp of $28 S$ rDNA region, respectively. The horizontal bar represents $0.005 \%$ differences in nucleotide identities 


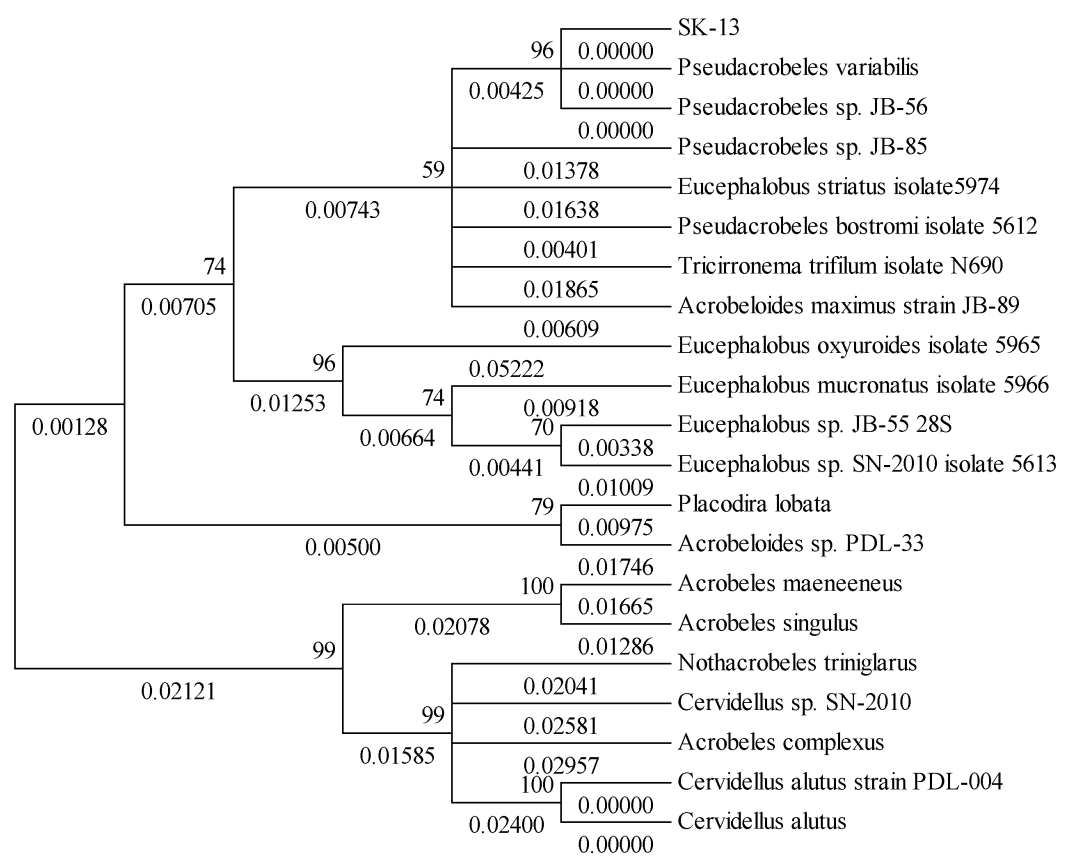

Figure 2. Phylogenetic relationships of different nematode species with SK-13 isolate. Phylogeny inferred from the alignment of the $620 \mathrm{bp}$ of $28 \mathrm{~S}$ rDNA. The horizontal bar represents $0.005 \%$ differences in nucleotide identities

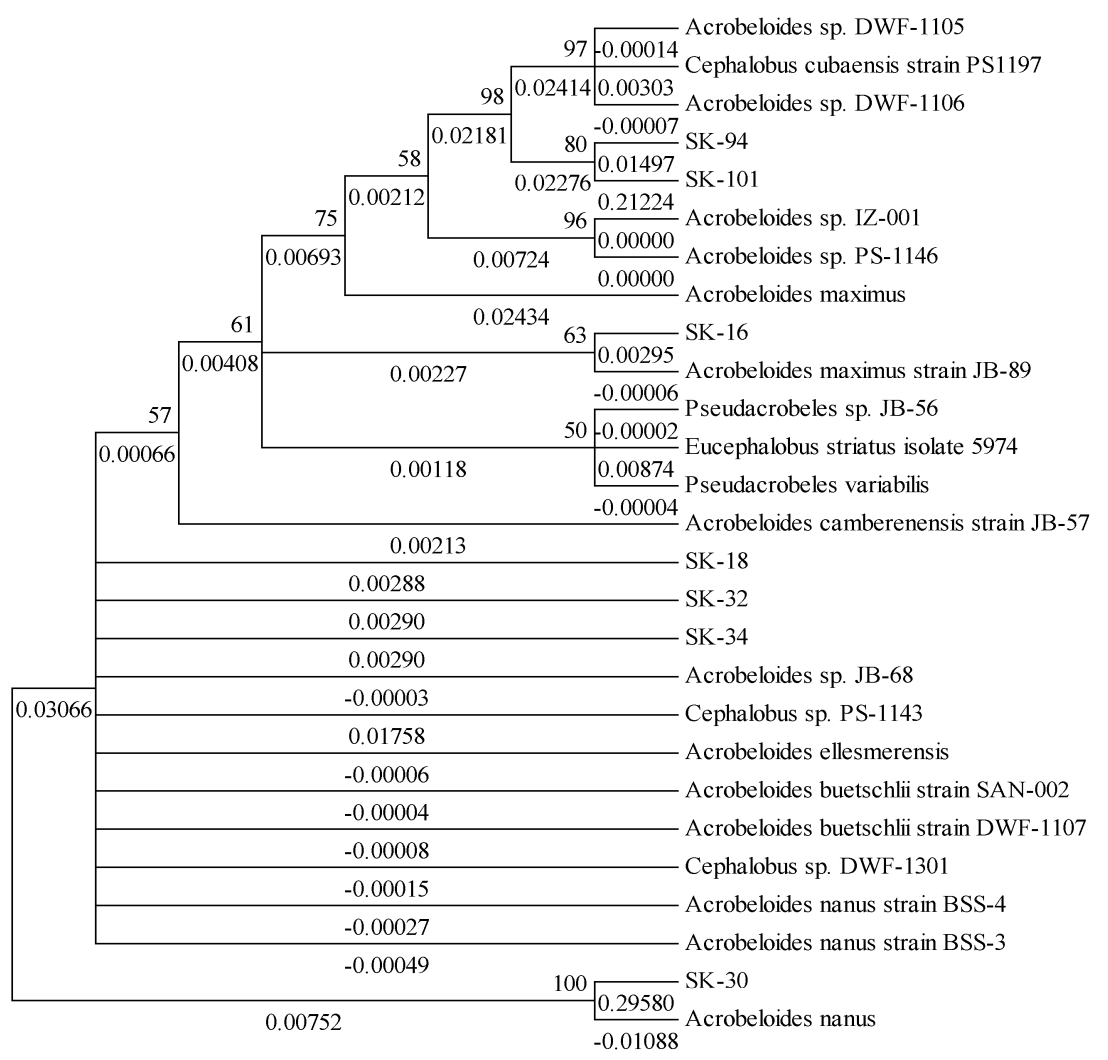

Figure 3. Phylogenetic relationships of different nematode species with SK-16, SK-18, SK-30, SK-32, SK-34, SK-94 and SK-101 isolates. Phylogeny inferred from the alignment of the 727, 919, 763, 752, 934, 679 and 684bp of 28S rDNA, respectively. The horizontal bar represents $0.005 \%$ differences in nucleotide identities 


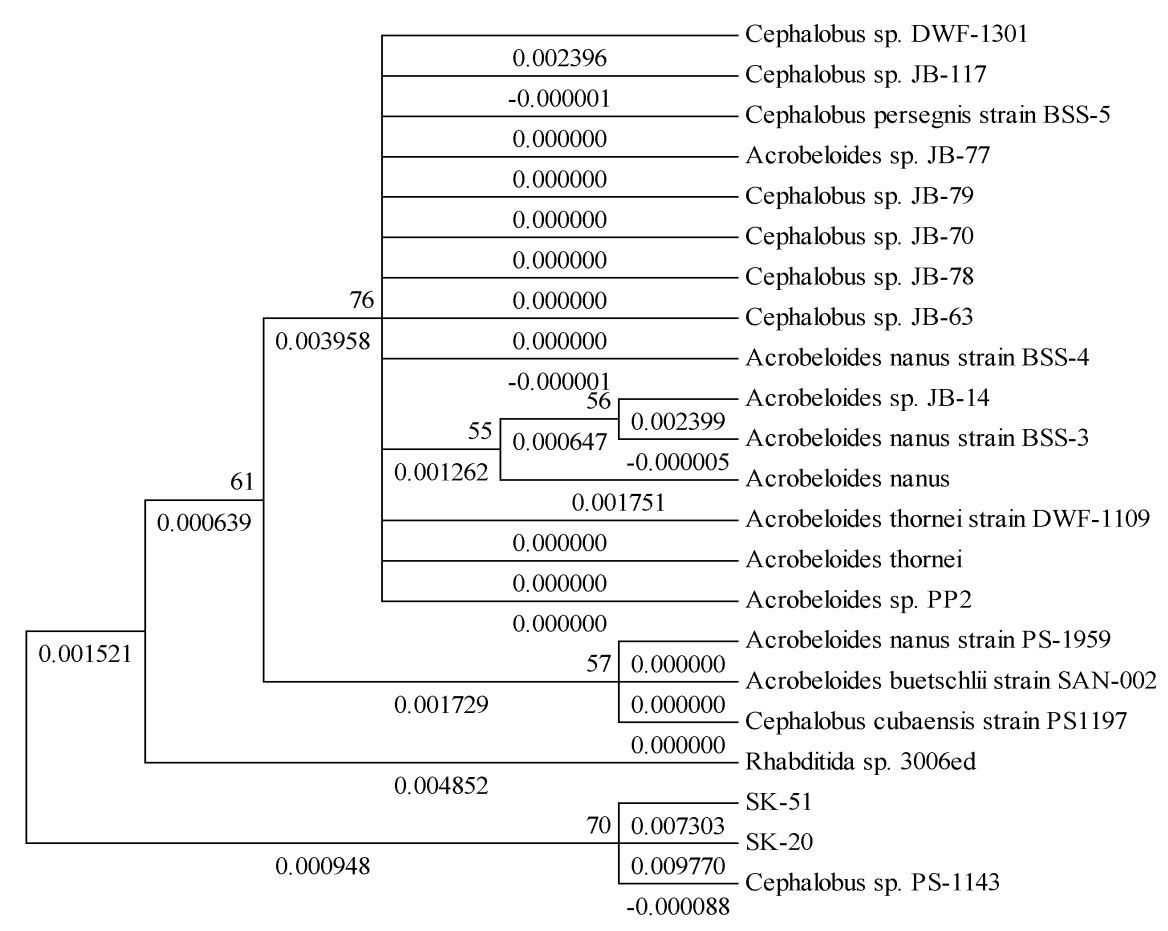

Figure 4. Phylogenetic relationships of different nematode species with SK-20 and SK-51 isolates. Phylogeny inferred from the alignment of the 746 and 927bp of $28 \mathrm{~S}$ rDNA, respectively. The horizontal bar represents $0.005 \%$ differences in nucleotide identities

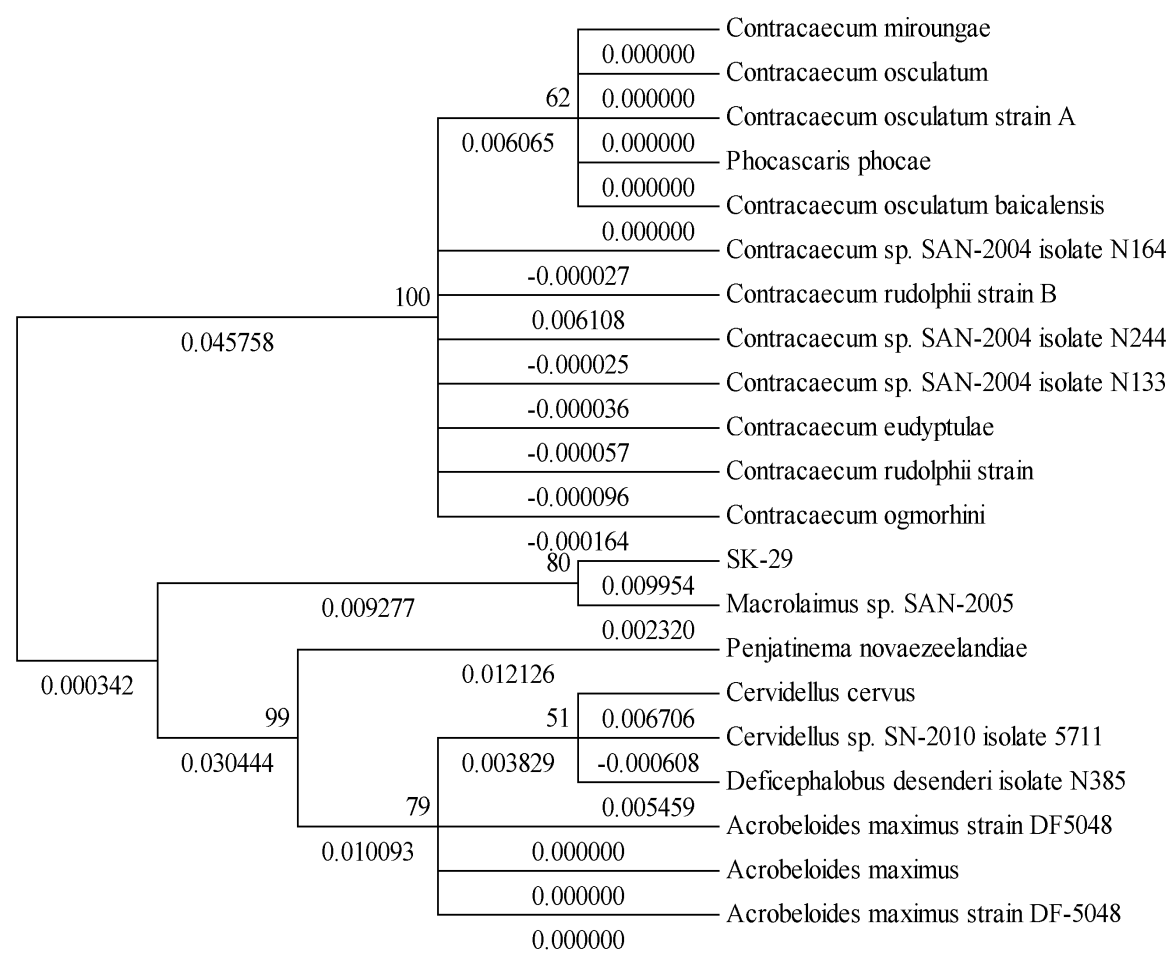

Figure 5. Phylogenetic relationships of different nematode species with SK-29 isolate. Phylogeny inferred from the alignment of the $632 \mathrm{bp}$ of $28 \mathrm{~S}$ rDNA. The horizontal bar represents $0.005 \%$ differences in nucleotide identities 


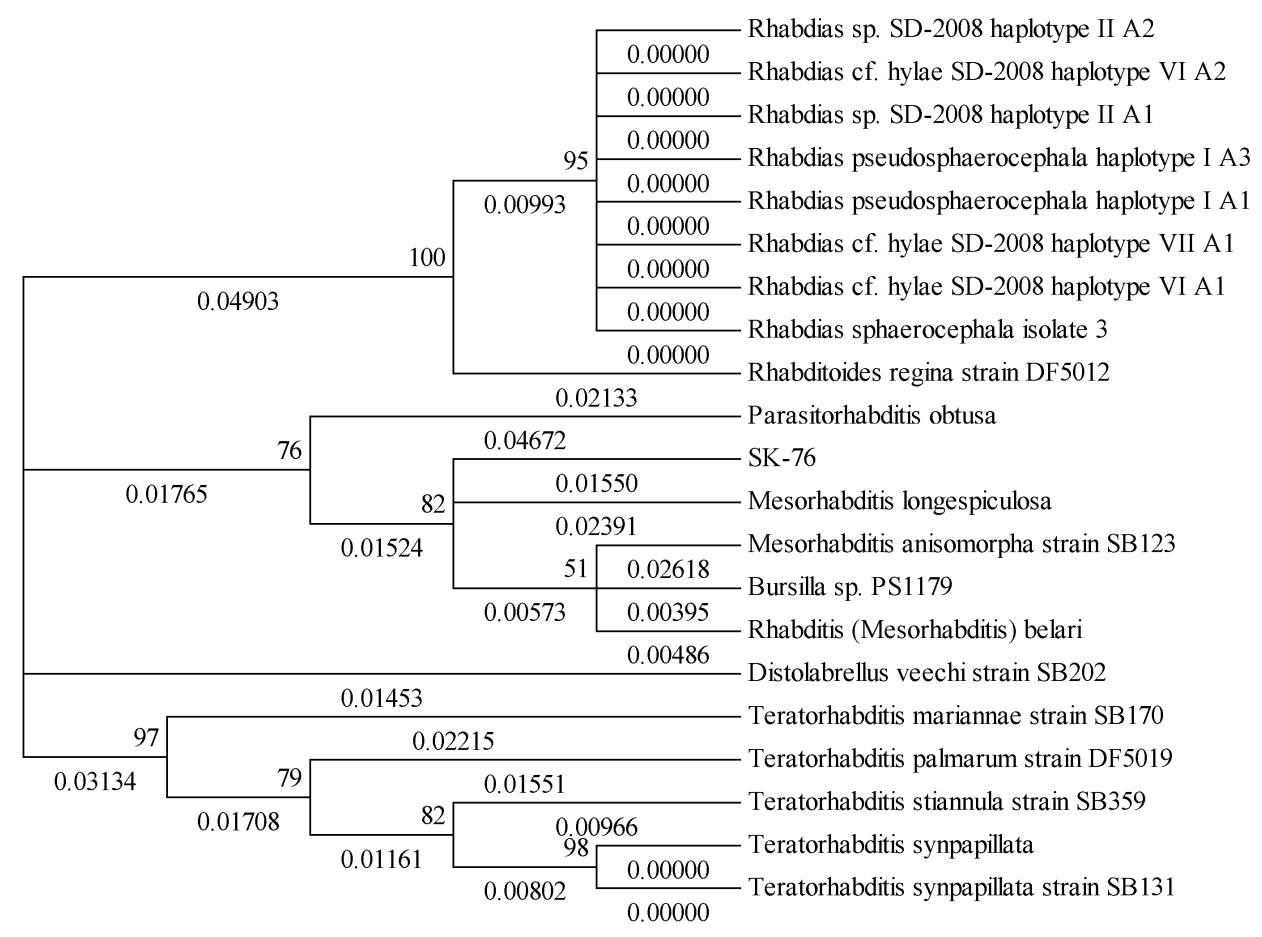

Figure 6. Phylogenetic relationships of different nematode species with SK-76 isolate. Phylogeny inferred from the alignment of the 688bp of $28 \mathrm{~S} \mathrm{rDNA}$. The horizontal bar represents $0.005 \%$ differences in nucleotide identities

\section{Discussion}

The free-living nematodes undertake an important role in nutrient cycling. Besides, contributions of these organisms to nutrient cycling, nitrogen mineralization and distribution have been well documented (Ferris et al., 1997, 1998; Neher, 2001). Entomopathogenic nematodes (Steinernematidae and Heterorhabditidae) are also included in free-living rhabditid nematode groups and used as excellent biocontrol agents for many insect pests (Grewal et al., 2005).

In this study, 14 free-living nematode isolates were determined. Free-living nematodes, isolated from different habitats of East-Mediterranean region of Turkey, were characterized after BLASTN homology and phylogenetic analysis based on Neighbor Joining and Bootstrap Tree methods. The free-living nematode isolates were identified as Rhabditis terricola (SK-3 and SK-75), Mesorhabditis sp. (SK-76) (Rhabditidae), Macrolaimus sp. (SK-29) (Chambersiellidae), Cephalobus sp. (SK-20 and SK-51), Pseudacrobeles sp. (SK-13) and Acrobeloides sp. (SK-16, SK-18, SK-30, SK-32, SK-34, SK-94 and SK-101) (Cephalobidae) from order Rhabditida. Isolates were mainly obtained from agricultural fields with a rate of $73.3 \%$. Rhabditis terricola strains were obtained from forest area, but Pseudacrobeles sp. and Mesorhabditis sp. strains were isolated from horticultural fields of different regions. On the other hand Cephalobus sp. and Macrolaimus sp. strains were also isolated from various agronomical fields. Acrobeloides sp. strains were collected from grassland, agronomical and horticultural fields. Our results indicated that the free-living nematodes can be obtained from habitats as forest, grassland and agricultural fields. Abolafia and Pena- 
Santiago (2007) supports our finding in that rhabditid nematodes are very abundant in all types of soil and sediments.

In the current study, the free-living nematode strains (Rhabditis terricola, Pseudacrobeles sp., Mesorhabditis sp., Cephalobus sp., Macrolaimus sp. and Acrobeloides sp.) were isolated from last instar G. mellonella larvae cadavers. Large numbers of Rhabditis terricola determined in earthworm cocoons (Lumbricus rubellus, Hoffmeister and Eisenia foetida, Savigny) and earthworm cultures suffered extensive productivity loss (Taboga, 1981). The relationship of the Rhabditis species with arthropods could be described as phoretic, moderately pathogenic, and facultatively parasitic (Carta and Osbrink, 2005). Poinar (1971) reported that Rhabditis adenobia Poinar lived and reproduced within the colleterial glands and endophallic passages of the male dynastid beetle Oryctes monoceros L. (Col.: Scarabaeidae) without apparent harm to the host. $R$. brevispina (Claus) was found on the body surface of mole crickets, Gryllotalpa unispina (Ort.: Gryllotalpidae) and has phoretic relationship (Gulyamova, 1990).

Rhabditis sp. nematodes are also reported as opportunistic invader of cadavers (Garcia et al., 2011). However, Rhabditis blumi Sudhaus showed high pathogenicity $(>78 \%)$ against major cruciferous insect pests, Artogeia rapae L. (Lep.: Pieridae), Mamestra brassicae L. (Lep.: Noctuidae) and Plutella xylostella L. (Lep.: Plutellidae) in laboratory experiments (Park et al., 2012). Dauer larvae of Rhabditis rainai Carta and Osbrink (2005) experimentally infested two subterranean termite species Reticulitermes flavipes Kollar and R. hesperus Banks (Massey, 1971). Schulte (1989) reported that Rhabditis (Oscheius) necromena Sudhaus and Schulte infected three millipede species, Australian Akamptogonus novarae (Humbert and Saussure) (Dipl.: Paradoxosomatidae), Australian Oncocladostoma castaneum (Attems) (Dipl.: Paradoxosomatidae) and Portuguese pest Ommatoiulus moreletii (Lucas) (Dipl.: Julidae) at different levels. It is also reported that dauer juveniles of $R$. necromena remain inside the haemocoel of this host until it dies and resume their development after feeding on bacteria present in the decaying carcass ('necromeny'). Moreover, soil bacteria that are attached to the surface of the invading nematode juveniles regularly cause a lethal contamination in the nonadapted O. moreletii (Massey, 1971). It was also reported that Rhabditis species use many mollusk species as host (Grewal et al., 2003).

Mesorhabditis irregularis (Körner) was found on body surface of mole crickets, $G$. unispina. M. irregularis was associated only with host phoretically (Poinar, 1971). M. irregularis and M. quercophila (Rühm) were observed in Melolontha afflicta Ball. (Col.: Scarabaeidae). M. oschei Körner has relationship with Ips sexdentatus (Börner) (Col.: Curculionidae) (Grewal et al., 2003). On the other hand M. spiculigera species were ectoparasite of Scarabaeus sacer (Col.: Scarabaeidae) (El-Kifl et al., 1971). Macrolaimus species are commonly recovered from bark infested with beetles and they may be carried by other insects (Massey, 1974). M. canadensis isolated from the frass of the bark beetle Phloeosinus canadensis Swaine (Col.: Curculionidae) (Sanwal, 1960). M. crucis was isolated from Pissodes piniphilus Herbst. (Col.: Curculionidae) (Poinar, 1975). The other species belong the genus Cephalobus was indicated to have interaction with some mollusks, annelids and insect species. Cephalobus (Acrobeloides) buetschlii de Man and $C$. persegnis use mollusk species Polygyra albolabrus Say and Helix hortensis Muller as host (Grewal et al., 2003). C. persegnis species was determined to have infestation on earthworm cocoons and act as ectoparasite on Scarabaeus sacer L. (Col.: Scarabaeidae) (El-Kifl et al., 1971). No study has been conducted previously 
concerning the relationship of Pseudacrobeles and Acrobeloides with insect and arthropod species. However, Acrobeloides nanus (De Man) infestation was reported in earthworm cocoons (Kraglund and Ekelund, 2002). Contribution of free-living nematodes to soil nutrient cycle and soil mineralization are evident. During these processes, free-living nematodes interact with many arthropods and other invertebrate species. Interactions of free living nematodes with arthropods and other invertebrates vary from phoretic to pathogenic relations. These interactions are also important for their use in biological control program. However, more detailed studies need to be carried out to clarify these relationships.

Acknowledgments. This investigation was supported by the Research Fund of Erciyes University (FBD10-3267).

\section{REFERENCES}

[1] Abolafia, J., Pena-Santiago, R. (2007): Nematodes of the order Rhabditida from Andalucía Oriental, Spain. The genera Protorhabditis (Osche, 1952) Dougherty, 1953 and Diploscapter Cobb, 1913, with description of P. spiculocrestata sp. n. and a species Protorhabditis key. - Journal of Nematology 39: 263-274.

[2] Baldwin, J.G., Nadler, S.A., Freckman, D.W. (1999): Nematodes-pervading the earth and linking all life. In Raven PH, Williams T, editors. Proceedings of the Second National Forum on Biodiversity, Nature and Human Society. The Quest for a Sustainable World. Washington: National Academy Press; p. 176-191.

[3] Bedding, R.A. (1975): Akhurst RJ. A simple technique for the detection of insect parasitic Rhabditid nematodes in soil. - Nematologica 21: 109-110.

[4] Blaxter, M.L., De Ley, P., Garey Liu, J.R., Liu, L.X., Scheldeman, P., Vierstraete et al., (1998): A molecular evolutionary framework for the phylum Nematoda. - Nature 392: 7175 .

[5] Campos-Herrera, R., El-Borai, F.E., Duncan, L.W. (2012): Wide interguild relationships among entomopathogenic and free-living nematodes in soil as measured by real time qPCR .- Journal of Invertebrate Pathology 111: 126-235.

[6] Carrascosa, M., Sanchez-Moreno, S., Alonso-Prados, J.L. (2014): Relationships between nematode diversity, plant biomass, nutrient cycling and soil suppressiveness in fumigated soils. - European Journal of Soil Biology 62: 49-59.

[7] Carta, L.K., Osbrink, W. (2005): Rhabditis rainai n. sp. (Nematoda. Rhabditida) associated with the Formosan subterranean termite, Coptotermes formosanus (Isoptera. Rhinotermitidae). - Nematology 7: 863-879.

[8] De Ley, P., Felix, M.A., Frisse, L.M., Nadler, S.A., Sternberg, P.W., Thomas, W.K. (1999): Molecular and morphological characterisation of two reproductively isolated species with mirror-image anatomy (Nematoda. Cephalobidae). - Nematology 1: 591612.

[9] De Ley, P., Blaxter, M.L. (2002): Systematic position and phylogeny. In Lee DL, editor. The Biology of Nematodes. - London: Taylor and Francis; p. 1-30.

[10] Derycke, S., Fonseca, G., Vierstraete, A., Vanfleteren, J., Vincx, M., Moens, T. (2008): Disentangling taxonomy within the Rhabditis (Pellioditis) marina (Nematoda, Rhabditidae) species complex using molecular and morhological tools. - Zoological Journal of The Linnean Society London 152: 1-15.

[11] Duncan, L.W., Dunn, D.C., Bague, G., Nguyen, K. (2003): Competition between entomopathogenic and free-living bactivorous nematodes in larvae of the weevil Diaprepes abbreviates. - Journal of Nematology 35: 187-193. 
[12] El-Kifl, A.H., Abdel-Wahab, A.I., Ali, M.A.M. (1971): Some insects parasitized by nematodes in Egypt. - Bulletin Societe Entomologique Egypte 54: 87-99.

[13] Ferris, H., Venette, R.C., Van Der Meulen, H.R., Lau, S.S. (1998): Nitrogen mineralization by bacterial-feeding nematodes: Verification and measurement. - Plant Soil 203: 159-171.

[14] Ferris, H.R., Venette, C., Lau, S.S. (1997): Population energetics of bacterial-feeding nematodes. Carbon and nitrogen budgets. - Soil Biology and Biochemistry 29: 11831194.

[15] Garcia, J.M., Jenkins, D., Chavarria, J.A., Shapiro-Ilan, D.I., Goenaga, R. (2011): Interactions of a Rhabditis sp. on the virulence of Heterorhabditis and Steinernema in Puerto Rico. - Florida Entomologist 94: 701-702.

[16] Grewal, P.S., Ehlers, R.U., Shapiro-Ilan, D.I. (2005): Nematodes as biological control agents. - Wallingford: CAB International Publishing p: 505.

[17] Grewal, P.S., Grewal, S.K., Tan, L., Adams, B.J. (2003): Parasitism of molluscs by nematodes: Types of associations and evolutionary trends. - Journal of Nematology 35: $146-156$.

[18] Gulyamova, D.B. (1990): Nematodes of mole cricket (Gryllotalpa unispina) in Ferghana district. - In: Sonin, M.D. (ed) Helminths of insects. New Delhi: Oxonian Press Pvt Ltd., pp. 51-52.

[19] Karabörklü, S. (2012): Isolation and identification of entomopathogenic nematodes from different regions and their use as biological control agent on pine processionary moth (Thaumetopoea wilkinsoni Tams). PhD Dissertation. Erciyes University, Graduate School of Natural and Applied Sciences: Kayseri.

[20] Karabörklü, S., Ayvaz, A., Yilmaz, S., Azizoglu, U., Akbulut, M. (2015a): Native entomopathogenic nematodes isolated from Turkey and their effectiveness on pine processionary moth, Thaumetopoea wilkinsoni Tams. - International Journal of Pest Management 61: 3-8.

[21] Karabörklü, S., Ayvaz, A., Yilmaz, S., Azizoglu, U. (2015b): Fungi associated with freeliving soil nematodes in Turkey. - Archives of Biological Sciences 67: 1173-1183.

[22] Kaya, H.K., Stock, S.P. (1997): Techniques in insect nematology. In Lacey LA, editor. Manual of techniques in insect pathology. - San Diego: Academic Press p. 281-324.

[23] Kraglund, H.O., Ekelund, F. (2002): Infestation of natural populations of earthworm cocoons by rhabditid and cephalobid nematodes. - Pedobiologia 46: 125-135.

[24] Levi, T., Shermani, C., Pen-Mouratov, S., Steinberger, Y. (2012): Changes in soil freeliving nematode communities and their trophic composition along a climatic gradient. Open Journal of Ecology 2: 79-89.

[25] Massey, C.L. (1971): Two new genera of nematodes parasitic in the eastern subterranean termites Reticulitermes flavipes. - Journal of Invertebrate Pathology 17: 238-242.

[26] Massey, C.L. (1974): Biology and Taxonomy of nematode parasites and associates of bark beetles in the United States. Agriculture handbook no. 446. Washington: USDA forest service, p: 233.

[27] Nadler, S.A., Hudspeth, D.S.S. (1998): Ribosomal DNA and phylogeny of the Ascaridoidea (Nemata: Secernentea): implications for morphological evolution and classification. - Molecular Phylogenetics and Evolution 10: 221-236.

[28] Nadler, S.A. (2002): Species delimitation and nematode biodiversity. Phylogenies rule. Nematology 4: 615-625.

[29] Nadler, S.A., Carreno, R.A., Adams, B.J., Kinde, H., Baldwin, J.G., Mundo-Ocampo, M. (2003): Molecular phylogenetics and diagnosis of soil and clinical isolates of Halicephalobus gingivalis (Nematoda. Cephalobina. Panagrolaimoidea), an opportunistic pathogen of horses. - International Journal for Parasitology 33: 1115-1125.

[30] Neher, D.A. (2001): Role of nematodes in soil health and their use as indicators. - Journal of Nematology 33: 161-168. 
[31] Park, H.W., Kim, H.H., Youn, S.H., Shin, T.S., Bilgrami, A.L., Cho, M.R., Shin, C.S. (2012): Biological control potentials of insect-parasitic nematode Rhabditis blumi (Nematoda. Rhabditida) for major cruciferous vegetable insect pests. - Applied Entomology and Zoology 47: 389-397.

[32] Poinar, G.O. (1971): Rhabditis adenobia sp. n. (Nematoda. Rhabditidae) from the colleterial glands of Oryctes monoceros L. and other tropical dynastid beetles (Coleoptera. Scarabaeidae). - Proceedings of the Helminthological Society of Washington 38: 99-108.

[33] Poinar, G.O. (1975): Entomogenous nematodes. A manual and host list of insectnematode associations. - Leiden: Brill p: 317.

[34] Sanwal, K.C. (1960): Macrolaimus canadensis n. sp. (Nematoda. Panagrolaiminae), from the frass of the bark beetle Phloeosinus canadensis swaine, 1917, with remarks on other species of the genus Macrolaimus Maupas, 1900. - Canadian Journal of Zoology 38: 1127-1131.

[35] Schulte, F. (1989): The association between Rhabditis necromena Sudhaus and Schulte, 1989 (Nematoda. Rhabditidae) and native and introduced millipedes in South Australia. Nematologica 35: 82-89.

[36] Stock, S.P., Campbell, J.F., Nadler, S.A. (2001): Phylogeny of Steinernema Travassos, 1927 (Cephalobina. Steinernematidae) inferred from ribosomal DNA sequences and morphological characters. - Journal of Parasitology 87: 877-889.

[37] Subbotin, S.A., Sturhan, D., Chizhov, V.N., Vovlas, N., Baldwin, J.G. (2006): Phylogenetic analysis of Tylenchida Thorne, 1949 as inferred from D2 and D3 expansion fragments of the 28S rRNA gene sequences. - Nematology 8: 455-474.

[38] Taboga, L. (1981): Rhabditis terricola. An opportunistic nematode parasite of earthworm cocoons. - Journal of Invertebrate Pathology 38: 2-25.

[39] Tamura, K., Peterson, D., Peterson, N., Stecher, G., Nei, M., Kumar, S. (2011): MEGA5. Molecular evolutionary genetics analysis using maximum likelihood, evolutionary distance, and maximum parsimony methods. - Molecular Biology and Evolution 28: 2731-2739.

[40] Wang, K.H., Mcsorley, R., Marshall, A.J., Gallaher, R.N. (2004): Nematode community changes associated with decomposition of Crotalaria juncea amendment in litterbags. Applied Soil Ecology 27: 31-45.

[41] Williams, B.D., Schrank, B., Huynh, C., Shownkeen, R., Waterston, R.H. (1994): A genetic mapping system in Caenorhabditis elegans based on polymorphic sequencetagged sites. - Genetics 131: 609-24.

[42] Yeates, G.W., Wardle, D.A. (1996): Nematodes as predators and prey: relationships to biological control and soil processes. - Pedobiologia 40: 43-50.

[43] Yeates, G.W., Bongers, T., De Goede, R.G.M., Freckman, D.W., Georgieva, S.S. (1993): Feeding habits in soil nematode families and genera- an outline for soil ecologists. Journal of Nematology 25: 315-331.

[44] Yilmaz, S., Ayvaz, A., Akbulut, M., Azizoglu, U., Karabörklü, S. (2012): A novel Bacillus thuringiensis strain and its pathogenicity against three important pest insects. Journal of Stored Products Research 51: 33-40.

[45] Zhang, C., Liu, J., Xu, M., Sun, J., Yang, S., An, X., et al. (2008): Heterorhabditidoides chongmingensis gen. nov., sp. Nov. (Rhabditida. Rhabditidae), a novel member of the entomopathogenic nematodes. - Journal of Invertebrate Pathology 98: 153-168. 